\title{
Implementation of Wireless Sensor Networks for Irrigation Control in Three Container Nurseries
}

\author{
Matthew Chappell ${ }^{1}$, Sue K. Dove, Marc W. van Iersel, \\ Paul A. Thomas, and John Ruter
}

ADDITIONAL INDEX WORDS. commercial horticulture production, container production, precision irrigation, soil moisture sensor

SUMMARY. Water quality and quantity are increasingly important concerns for agricultural producers and have been recognized by governmental and nongovernmental agencies as focus areas for future regulatory efforts. In horticultural systems, and especially container production of ornamentals, irrigation management is challenging. This is primarily due to the limited volume of water available to container-grown plants after an irrigation event and the resultant need to frequently irrigate to maintain adequate soil moisture levels without causing excessive leaching. To prevent moisture stress, irrigation of container plants is often excessive, resulting in leaching and runoff of water and nutrients applied to the container substrate. For this reason, improving the application efficiency of irrigation is necessary and critical to the long-term sustainability of the commercial nursery industry. The use of soil moisture sensing technology is one method of increasing irrigation efficiency, with the on-farm studies described in this article focusing on the use of capacitance-based soil moisture sensors to both monitor and control irrigation events. Since on-farm testing of these wireless sensor networks (WSNs) to monitor and control irrigation scheduling began in 2010, WSNs have been deployed in a diverse assortment of commercial horticulture operations. In deploying these WSNs, a variety of challenges and successes have been observed. Overcoming specific challenges has fostered improved software and hardware development as well as improved grower confidence in WSNs. Additionally, growers are using WSNs in a variety of ways to fit specific needs, resulting in multiple commercial applications. Some growers use WSNs as fully functional irrigation controllers. Other growers use components of WSNs, specifically the web-based graphical user interface (GUI), to monitor grower-controlled irrigation schedules.

$M$ anaging the quality and quantity of global freshwater resources is one of the most imperative environmental challenges of the 2 lst century, with agriculture accounting for $70 \%$ of all global freshwater use (Fischer et al., 2007). Population growth and increasing urbanization worldwide have elevated competition for freshwater resources among domestic, industrial, and agricultural users, with agricultural water use deemed unsustainable in many parts of the world (Gleeson

Department of Horticulture, University of Georgia Horticulture Department, 1111 Miller Plant Science Building, Athens, GA 30602

This paper is part of a series of manuscripts describing the research and development completed by the SCRI-MINDS (Managing Irrigation and Nutrition through Distributed Sensing) project. The authors gratefully acknowledge funding and support from the USDA-NIFA Specialty Crops Research Initiative; Award \#2009-51181-05768.

We sincerely thank Chris McCorkle, Will Ross, and David Freed for their assistance during the study.

${ }^{1}$ Corresponding author. E-mail: hortprod@uga.edu. et al., 2012; Jury and Vaux, 2005). As a growing segment of agriculture in the United States, horticulture is not immune to water quality and quantity issues. Several U.S. states have regulations in place and/or are under federal mandates related to watershed-based agricultural irrigation withdrawals, including specialty crop intensive areas such as the Chesapeake Bay watershed (Lea-Cox and Ross, 2001) and Florida (Beeson and Brooks, 2008). Further restrictions are predicted by researchers and commercial nursery producers throughout the United States in the future (Beeson, 2004;
Wilson and Albano, 2011). To meet the long-term freshwater needs of the world's population, it is critical to increase the efficiency of agricultural water use (Howell, 2001; Knox et al., 2012). The use of moisture sensing technology is a promising avenue to address irrigation efficiency without compromising crop quality.

The use of technology has historically been the cornerstone of improving irrigation efficiencies, first in arid lands and modernized nations (Gleick, 2010) and more recently in developing nations (Wu et al., 2010). Examples of irrigation system components used to increase irrigation uniformity in specialty crops include drip, microirrigation nozzles, and matched precipitation sprinkler nozzles. These technologies have been incorporated into best management practices for the production of ornamental crops (Chappell et al., 2013), with the goal of reducing runoff of nutrient- and pesticide-laden water from production sites (Briggs et al., 1998; Lea-Cox and Ross, 2001; Tyler et al., 1996). However, good uniformity is only part of what is needed to achieve high efficiency, with the other component being application of the appropriate amount of water, based on crop water needs. Yet, the greenhouse and nursery industry has to date made little progress in the latter area.

Recently released commercial irrigation controllers that have improved irrigation efficiency in specialty crops include evapotranspiration (ET)-based controllers (Beeson, 2010) and ET plus daily light integral (DLI)-based controllers (Nautiyal et al., 2010). Although appropriate for homeowner applications, these controllers have proven to lack the accuracy required for many commercial agriculture applications, as data are frequently gathered for calculation of ET from weather reporting stations distant from the production facility using the controller technology

\begin{tabular}{lllc}
\hline $\begin{array}{l}\text { Units } \\
\begin{array}{l}\text { To convert U.S. to SI, } \\
\text { multiply by }\end{array}\end{array}$ & U.S. unit & SI unit & $\begin{array}{l}\text { To convert SI to U.S., } \\
\text { multiply by }\end{array}$ \\
\hline 0.4047 & acre(s) & ha & 2.4711 \\
0.3048 & $\mathrm{ft}^{2}$ & $\mathrm{~m}$ & 3.2808 \\
0.0929 & $\mathrm{ft}^{2}$ & $\mathrm{~m}^{2}$ & 10.7639 \\
3.7854 & gal & $\mathrm{L}$ & 0.2642 \\
2.54 & inch(es) & $\mathrm{cm}$ & 0.3937
\end{tabular}


(Crookston and Hattendorf, 2012). Additionally, if located on-site, instrumentation used to calculate ET and DLI can be inaccurate because of improper installation, calibration, and/or maintenance (van Iersel et al., 2013). For this reason, a simpler to operate and maintain irrigation control system, based on sensing of environmental conditions, is required for long-term adoption and use in commercial horticulture systems.

Jones (2007) concluded that monitoring of soil water content is the most valuable measure of plant or soil water status for the purpose of irrigation scheduling, as soil moisture monitoring consolidates all environmental conditions (e.g., temperature, light levels, humidity) into one measurement. For this reason, researchers over the last decade have initiated studies on the plausibility of using soil-moisture-based irrigation control to improve irrigation efficiency (Burnett and van Iersel, 2008; GarciaNavarro et al., 2011; Miralles-Crespo and van Iersel, 2011; Warsaw et al., 2009). These studies indicate that using on-site, real-time sensing technology to monitor and control irrigation events serves three valuable purposes: 1) it reduces the number of environmental measures required to control irrigation to one, the volumetric water content of the soil or substrate; 2) it reduces the maintenance and calibration of sensors required to calculate an irrigation event to one, the capacitance-based soil moisture probe; 3 ) it uses on-farm data to determine soil moisture and therefore increases the precision and accuracy of environmental measurements compared with using measurements from off-site locations. Additionally, these data are easily integrated into existing, timer-based, irrigation systems and allows for easy automation (Jones, 2004). Despite this work, no automated irrigation control system based on soil moisture has been widely adopted by the greenhouse and nursery industry.

One reason for a lack of adoption of soil moisture-based sensor irrigation systems by the commercial nursery and floriculture industry has been a reluctance to implement any new irrigation technology without significant research, testing, and economic analysis; first in a controlled research setting and subsequently in on-farm settings. However, many soil moisture sensors have been developed in the last two decades (Blonquist et al., 2005) that can be used in specialty crop agriculture systems. This includes the widely adopted Acclima TDT control system (Acclima, Meridian, ID) developed for turfgrass applications (Blonquist et al., 2006). Yet, until recently, no soil-moisture-sensorbased control system (hardware) has been matched with a software package targeted to greenhouse and nursery producers.

Crops grown using WSNs in controlled research settings have included periwinkle [Catharanthus roseus (Kim and van Iersel, 2010; van Iersel et al., 2007)], lantana [Lantana camara (Kim and van Iersel, 2009)], ornamental cabbage [Brassica oleracea var. capitata (Miralles-Crespo and van Iersel, 2011)], hibiscus [Hibiscus acetosella (Bayer et al., 2013; Ferrarezi and van Iersel, 2011)], mophead hydrangea [Hydrangea macrophylla (O'Meara et al., 2011)], petunia [Petunia $\times$ bybrid (Kim et al., 2011; Peter et al., 2011)], and snapdragon [Antirrbinum majus (Kim et al., 2012)]. These controlled research studies have demonstrated the utility of sensor-controlled irrigation. The subsequent step in facilitating adoption of this technology has been the on-farm implementation of soilmoisture-based irrigation hardware and software developed as part of the U.S. Department of Agriculture (USDA) Specialty Crops Research Initiative (SCRI) project (Kohanbash et al., 2013; Lea-Cox et al., 2013).

The objective of this manuscript is to describe the implementation and use of these WSNs at three commercial nursery and greenhouse operations in Georgia.

\section{Materials and methods}

Grower collaborators. Two grower collaborators in Georgia, McCorkle Nurseries, Inc. (MNI) and Evergreen Nursery, Inc. (ENI) participated in the original USDASCRI project (Lea-Cox et al., 2013). These growers were selected based on diversity of plant material produced and container sizes, and their willingness to implement prototype systems within commercial production environments. MNI is a 500 -acre production facility located in Dearing, GA, that is primarily a woody shrub and tree container grower of mediumsized containers ( 3 to $15 \mathrm{gal}$ ) and also grows a limited selection of herbaceous perennials and flowering shrubs in smaller container sizes (1 to $2 \mathrm{gal}$ ). On-farm trials at MNI were conducted in a 2 -acre (2010 to present) and 4-acre (2012 to present) polycovered coldframe. ENI is an 8 -acre grower of herbaceous perennials located in Statham, GA. Container sizes at ENI range from 32-cell flats to l-gal containers, with on-farm trials conducted in seasonally covered $15 \times 48$-ft coldframes. Garden Design Nursery $^{\odot}$ (GDN) joined the project in 2013 and is a 5 -acre specialty propagator and grower of japanese maples (Acer japonicum and Acer palmatum) located in Danielsville, GA. Container sizes at GDN range from 2 to $65 \mathrm{gal}$, with on-farm trials conducted on gravel beds with seasonally applied shadecloth. All nurseries are located in USDA hardiness zone 8A, and water for all on-farm trials was supplied from groundwater and delivered via overhead sprinklers.

Wireless SENSOR NETWORK DEPLOYMENT. On-farm trials were initiated at MNI in Spring 2010, at ENI in Summer 2010, and at GDN in Spring 2013. In on-farm trials at MNI, deployment included two phases. In phase one (Spring 2010), irrigation controllers [Moisture Clik IL200-MC; Dynamax, Houston, TX (Fig. 1)] were deployed to compare MNI irrigation practices to soil-moisture-based irrigation control. Moisture Clik irrigation controllers were used initially because Decagon Devices (Pullman, WA) had yet to develop the hardware required to control irrigation. Flow meters (model 40; Badger Meter, Milwaukee,

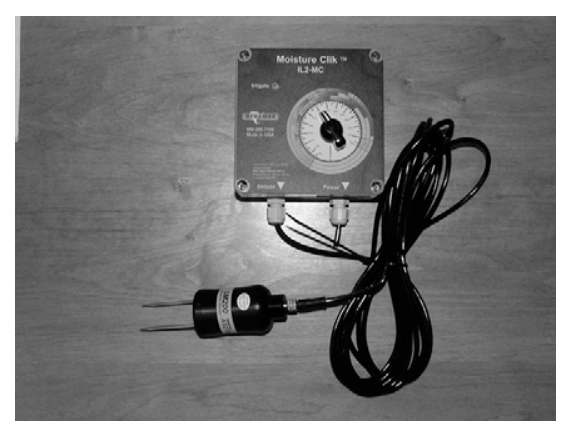

Fig. 1. Moisture Clik irrigation controller with SM200 soil moisture sensor (Dynamax, Houston, TX). Irrigation set point control is adjusted by turning the dial. 
WI) were installed to monitor water use in both plots. In phase two (Summer 2012), nR5 nodes (Fig. 2) with 10HS soil moisture sensors (Decagon Devices) were deployed to both monitor and control irrigation.

At ENI, deployment included two phases. In phase 1, EM50R nodes with EC- 5 soil moisture sensors (Decagon Devices) were installed to only monitor soil moisture. In phase two, nR5 nodes were added to enable both monitoring and control of irrigation. Using the nR5 node afforded both nurseries the ability to display data using SensorWeb (Kohanbash et al., 2013).

Additionally, growers in both nurseries could view environmental conditions (light, temperature, relative humidity, leaf wetness, vapor pressure deficit) collected using an EM50R node with ECRN-100 rain gauge, ETH temperature and humidity sensor, LWS leaf wetness sensor, and PYR total radiation sensor (Decagon Devices).

WEB-BASED GRAPHICAL USER INTERFACE. SensorWeb, developed by Carnegie-Melon University as part of this project (Kohanbash et al., 2013), allowed growers to view irrigation and environmental data while in monitoring-mode and send irrigation schedules to the nR5 node(s) when irrigation control was implemented. Throughout the entire project, growers and researchers constantly provided feedback on hardware, and more importantly software bugs and strengths, to create a GUI that best served the growers and allowed for software customization based on grower needs (Kohanbash et al., 2013).

Hardware installation. Installation of $\mathrm{nR} 5$ nodes differed at all three nurseries. The 2 -acre coldframe at MNI has a total of 54 irrigation valves, all powered using $24-\mathrm{V}$ [alternating current $(\mathrm{AC})]$. The coldframe was initially divided into eight separate irrigation zones, with six to seven valves per zone. The current draw of this many valves exceeded the rating of the relay in the nR5 node (rated for l A) that controls the power to the valves, making it impossible for the nR5 node to directly control all 54 valves simultaneously. Instead, the nR5 nodes were wired to the input side of a relay $(\mathrm{A} 2425 \mathrm{E}$ rated for $25 \mathrm{~A}$; Crydom, San Diego, CA), whereas solenoid wires were connected to the output side of the relay. This allowed the $\mathrm{nR} 5$ nodes to control the relay, which in turn controlled the power to the solenoids. It was necessary to connect a $2000-\Omega$ resistor (3WR2D0; Radio Shack, Fort Worth, TX) across the input terminals of the relay to prevent the build-up of a large enough voltage to trigger uncontrolled irrigation events that was the result of a leaking current from the circuit checking for $24-\mathrm{V}$ (AC). The number of nodes has since been scaled back to seven, with individual nodes controlling 6 to 13 valves, based on the crops that are currently grown in this greenhouse. The current setup provides MNI with much flexibility in how they can configure the system. They can

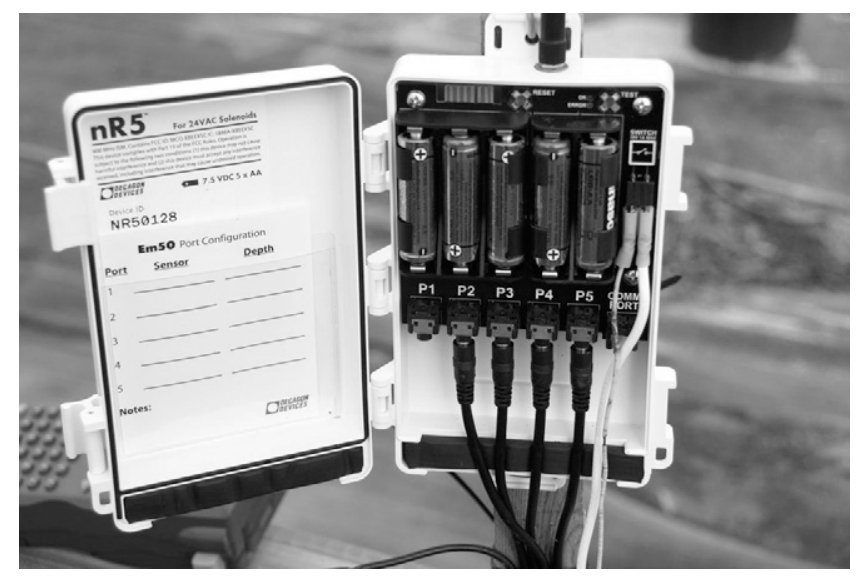

Fig. 2. An nR5 node (Decagon Devices, Pullman, WA) used as part of a wireless sensor network at McCorkle Nurseries (Dearing, GA). Up to five sensors can be plugged into the stereo ports at the bottom. On the right side, there is a relay that can be used to open and close irrigation valves. The nodes transmit all collected data to a base station and computer using a radio. easily change what valves are controlled by what node and are thus able to reconfigure the irrigation setup based on their production needs.

Installation of the $\mathrm{nR} 5$ nodes in the 4-acre coldframe at MNI and at ENI was simpler; the solenoid wires were connected directly to $24-\mathrm{V}$ (AC) transformers, and the relay in the $\mathrm{nR} 5$ nodes was used to interrupt and control the power supply to the existing solenoid valves. In the 4 -acre coldframe at MNI, each node controls a solenoid connected to a 4 -inch irrigation line, whereas at ENI each node controls one or two irrigation valves. At GDN, 24-V (AC) was not available and irrigation valves with latching 9-V [direct current (DC)] solenoids were used. This required the use of nR5-DC nodes. These nodes were specifically designed for use with latching valves powered by 9 to $12-\mathrm{V}$ (DC), where no 24-V (AC) was available. The two wires from the latching solenoids were connected directly to the power terminals inside the nR5DC nodes.

DOCUMENTING GROWER ADOPTION OF WIRELESS SENSOR NETWORKS. Throughout the on-farm implementation of soil-moisture-based WSN, grower behaviors pertaining to the use of WSNs were documented. Included were how quickly the grower switched from monitoring of soil moisture to controlling irrigation, the size of monitored and controlled area over time, the number of crops monitored and controlled over time, grower issues related to troubleshooting over time, changes in whole-farm irrigation practices based on WSN-irrigated sections of the growing operation, and longevity of hardware components. Although not a formal survey, our documentation of these factors has facilitated an understanding of how three unique growers implement, maintain, expand, and rely on WSN monitoring data and control capabilities, and how growers are integrating WSNs into existing irrigation infrastructure. Results are presented as case studies at the three participating grower cooperators.

\section{Results and discussion}

McCorkle nurseries. Trials were initiated in 2008, before SCRI grant-related activities. Initially, four Moisture Clik irrigation controllers were installed in a 0.5 -acre covered 
production area to control substrate water content in 'Mini Penny' mophead hydrangea. The objective of this trial was to compare water use in plots controlled using Moisture Clik irrigation controllers to standard MNI practices. Our findings showed that plots irrigated using the Moisture Clik controllers received $83 \%$ less water than plots irrigated using standard MNI practices (van Iersel et al., 2009). Although management at MNI was impressed with this reduction in water use, MNI management was not sold on the concept, largely because there was no clear financial incentive for reducing water use. It has become clear that water savings alone would not result in implementation of WSNs at MNI (or many other southeastern U.S. growers), principally because there is no cost for well or surface water in Georgia and pumping costs are negligible compared with other production costs.

After the start of the SCRI Managing Irrigation and Nutrition via Distributed Sensing (MINDS) project, we discussed with MNI management how their nursery might receive the maximum economic benefit from using WSNs. The factor deemed most important by MNI management was the ability to reduce crop shrinkage (mortality) in high-value "problem crops," such as gardenia (Gardenia jasminoides). The hope was that by better control of soil moisture, and hence reducing soil-borne pathogen pressure, disease incidence and shrinkage could be reduced. In 2011 , we set up a study similar to the 2008 trial, using 'MADGAl' ('Heaven Scent ${ }^{\circledR}$ ) gardenia as the crop, because of its susceptibility to a variety of soil-borne pathogens, with typical losses approaching 30\%. By monitoring and controlling irrigation using soil moisture sensors, we hoped to minimize overwatering and reduce disease pressure and associated losses. Surprisingly, we found that water use was similar between plots irrigated by MNI and sensor-controlled plots. Unbeknown to us, MNI's irrigation manager adjusted the irrigation in MNI control plots to match the volume of water that was applied in plots controlled by our Moisture Clik controllers, using flow meter readings that tracked irrigation volumes in the two treatments. Although this negated our ability to compare the different irrigation treatments, this highlights the educational opportunities that sensorbased irrigation can afford irrigation managers; as the irrigation manager learned how the better irrigate this gardenia crop, he also changed (reduced) irrigation across a large adjacent production area $(\approx 80$ acres $)$ that included dozens of species and cultivars. This was the first indication that providing growers quantitative information on water use of a single crop can have an impact that goes well beyond that crop.

Although this study appeared to be a loss from an irrigation comparison perspective, we noticed that disease incidence was negligible within this crop. No plants were lost due to root pathogens, although some plants were unsalable because of problems with algae clogging irrigation nozzles. Additionally, plants grew much faster than historically witnessed. Production time decreased from the anticipated 14 months to 5 to 8 months (Fig. 3). By reducing shrinkage and shortening the production cycle, the annualized profit increased by $\$ 2.80 / \mathrm{ft}^{2}$ (Lichtenberg et al., 2013). This value takes into account the reduced need for fungicide applications and the opportunity to start growing another crop in this highly valued greenhouse space. The payback time for wireless networks is very short with such financial return. Although excited about the 2011 results, MNI management and we were reluctant to believe that these results were due entirely to more precise irrigation. We thus grew another gardenia crop with sensor-controlled irrigation in the following (2012-13) production cycle.

Following the 2011 gardenia trial, a WSN was installed at MNI. This sensor network included nR5 nodes, which fully automated irrigation control of the entire 2 -acre production house, and one EM50R node that was configured as a weather station. Unlike the Moisture Clik controllers, the nR5 monitoring and control system collects data, which are radioed to a nearby base station and attached computer. This computer runs the SensorWeb GUI software, which can display the data and allows users to adjust irrigation settings. SensorWeb also allows users remote access over the Internet (Kohanbash et al., 2013).

The following gardenia irrigation control study was initiated in 2012 and results were consistent with those from 2011. The 2012-13 'Heaven Scent' gardenia crop was the first crop grown completely using the WSN at MNI. The crop was started on 18 June 2012, with an anticipated finish date of July 2013. Growth of the plants was much faster than anticipated, and some of the plants were ready for sale in Sept. 2012, with all plants reaching a salable size by Nov. 2012, 6 months before the anticipated sale date. Due to market limitations, MNI did not sell most of the plants at the point they were ready, yet crop losses due to disease pressure were again negligible and crop quality was high. Although economic data are not yet available for this crop, we expect the economic benefit of using

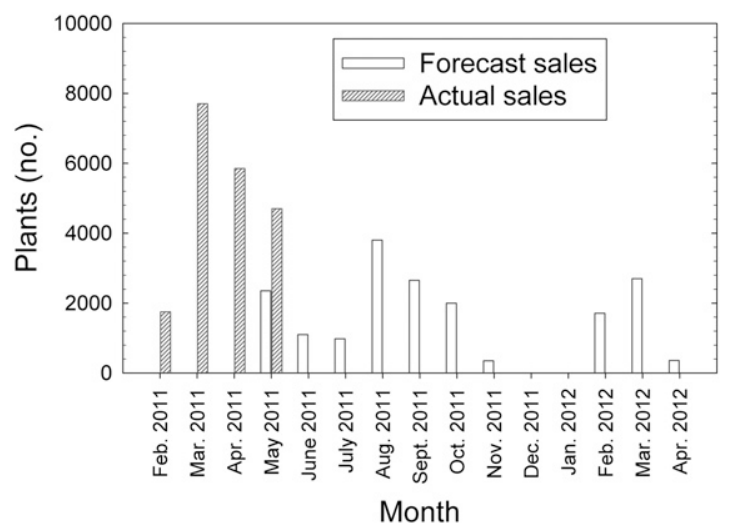

Fig. 3. Forecast and projected sales of 'MADGAl' ('Heaven Scent ${ }^{\circledR}$ ) gardenia grown using wireless sensor network controlled irrigation in 2010-11. Better control of irrigation resulted in much improved growth and earlier sales. The shorter production cycle reduced production costs and increased annualized profits by $\$ 2.80 / \mathrm{ft}^{2}\left(\$ 30.139 / \mathrm{m}^{2}\right)$. 
the WSN to mirror 2011 (Lichtenberg et al., 2013). MNI management was convinced that WSNs were capable of providing both production and financial benefits and were eager to expand the WSN. As a result, the research team installed two additional nR5 nodes (with EC-5 sensors) in a separate, 4 -acre covered house with a variety of mophead hydrangea cultivars in Fall 2012. Initial results in this house have been promising in that crop growth and health appear excellent, despite the fact a wide variety of cultivars, with varying planting dates, are being produced in this house in a variety of container sizes. MNI management has adopted the WSN technology and is currently awaiting commercial release by Decagon Devices to expand its use at the nursery. To date, only one system malfunction has occurred, with a direct lightning strike causing the failure of one node in July 2012.

EVERGREEN NURSERY. The initial setup of the WSN at ENI was initiated in 2010 , before $\mathrm{nR} 5$ nodes were available. Therefore, the initial WSN at ENI consisted of three EM50R nodes with EC-5 soil moisture sensors to monitor substrate water content and rain gauges to monitor irrigation and rainfall events. These nodes were used to monitor substrate water content in several different crops [e.g., gaillardia (Gaillardia Xgrandiflora), heuchera (Heuchera sanguinea), and wood ferns (Drysopteris sp.)]. An additional EM50R node functioned as a weather station. Data were sent by radio to a DataStation (Decagon Devices), which allowed for real-time display of the data using DataTrac software (Decagon Devices). The grower at ENI monitored the system frequently, often several times daily, and used the information to make irrigation decisions. ENI has focused on using the WSN data to reduce leaching. Since we had remote access to ENI's computer and were able to monitor the data, we worked closely with ENI on interpreting the data. We looked specifically at the rate of decrease in substrate water content following irrigation. Since ENI uses small containers, a rapid decline in substrate water content following irrigation is indicative of leaching, rather than the water draining to part of the substrate below the sensor (van Iersel et al., 2013). It became clear that in some cases (e.g., in a house with both lantana and gaillardia), substrate water content decreased very rapidly following irrigation, more rapidly than could be attributed to plant water use alone, and thus suggesting leaching as the likely cause. We discussed these results with the grower at ENI, who decided to change irrigation from once per day to twice per day, but for shorter periods, beginning on 14 Oct. 2010 (Fig. 4). The rapid decrease in substrate water content after irrigation disappeared at this time, indicating that this change in practice had reduced leaching.

Based on these findings, we worked with Carnegie-Mellon University cooperators to develop the Delta VWC tool that has since been incorporated as a tool within SensorWeb and later DataTrac. This Delta VWC tool shows the change in substrate water content since the previous measurement and is ideally suited for monitoring leaching. This is an example of how grower needs have resulted in software improvements developed as part of this project. ENI has observed reductions in total water use and leaching, as well as a corresponding, albeit anecdotal, increase in the longevity of controlledrelease fertilizers and improvement in crop health and growth rates.

Unlike MNI management, who valued the WSNs based on the system's ability to control irrigation and reduce crop shrinkage and increase profits, ENI valued the information generated by the WSN's monitoring capability, even without the capability

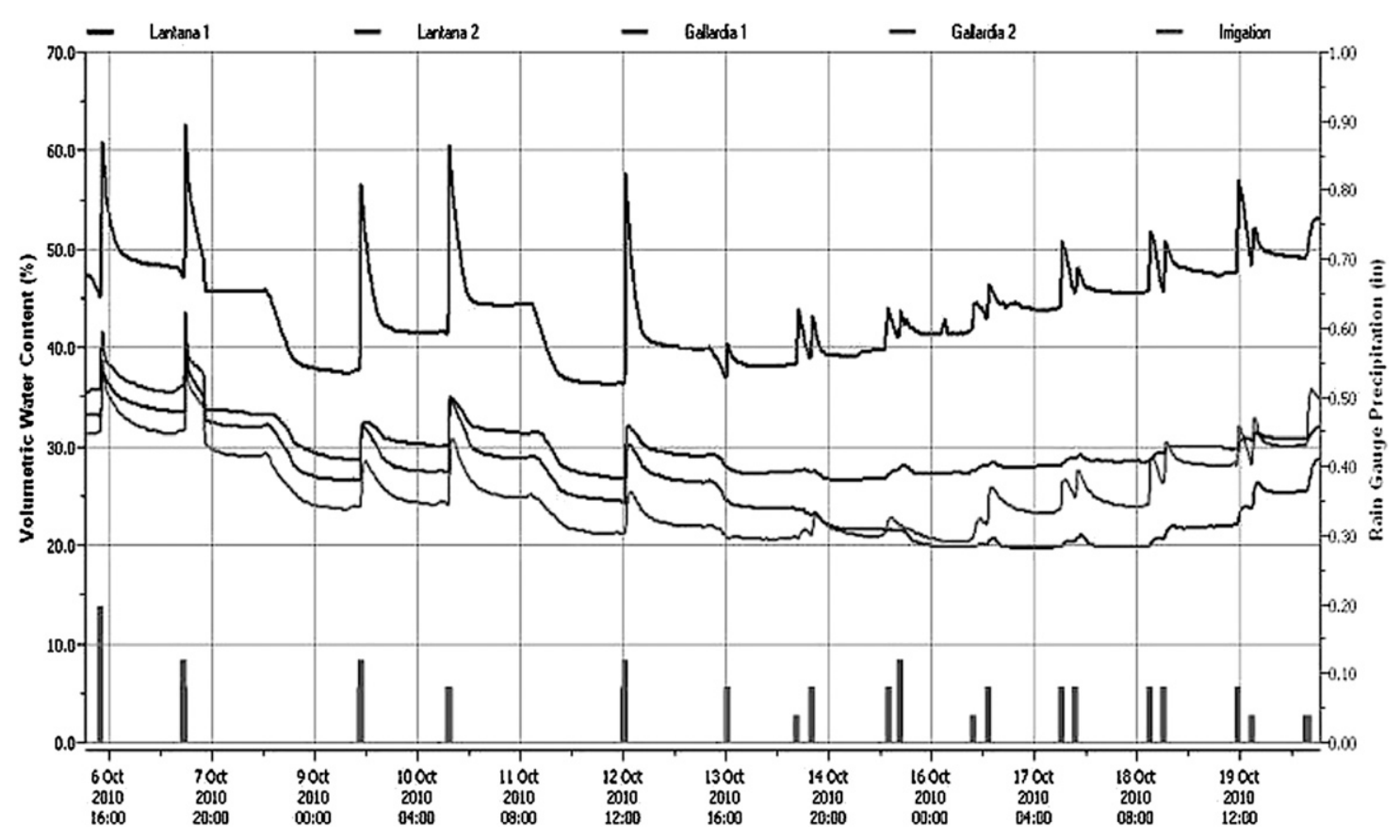

Fig. 4. A screenshot of the computer at Evergreen Nursery (Statham, GA), displaying substrate water content measurements (gray lines) and irrigation as monitored by a rain gauge (vertical bars in bottom of chart). Note the switch from once to twice daily irrigation scheduling on 14 Oct. $2010 ; 1 \mathrm{inch}=2.54 \mathrm{~cm}$. 
of automated irrigation control. This may be because the crops being grown at ENI are in smaller containers with quicker dry-down than at MNI, resulting in a more frequent need for irrigation and thus making real-time information even more valuable.

In Summer 2012, the WSN at ENI was upgraded, with the addition of five $\mathrm{nR} 5$ nodes. The $\mathrm{nR} 5$ nodes are controlling irrigation in five seasonally covered hoop houses. Crops grown in these sections include l-gal heucheras, euphorbs (Euphorbia sp.), echinacea (Echinacea sp.), lavender (Lavandula sp.), wood ferns, hosta (Hosta sp.), and hellebores (Hellebores orientalis). The automated irrigation control began in early Aug. 2012, but it is still too early to determine if there are clear effects on crop health or production. However, with the exception of a direct lightning strike disabling two nodes, all nodes are functioning properly. ENI developed a new shade production area in Spring 2013, and this area was designed specifically to facilitate the use of WSNs. An additional four $\mathrm{nR} 5$ nodes have been installed in this area to automate irrigation control. To date, only one malfunction has occurred, with a direct lightning strike causing the failure of two nR-5 AC nodes in July 2013.

Additionally, ENI has recently begun experimenting with different soilless substrates and wetting agents to increase the water-holding capacity of the substrate and is using the WSN to monitor substrate water levels in the various substrates. This real-time monitoring would not be possible without the WSN and will allow ENI to make a more informed decision when selecting substrates.

GaRden DESIGN NURSERY. The GDN network was installed in Spring 2013 , irrigating a 1 -acre production area. GDN's owner was aware of the WSN work being conducted at ENI and was enthusiastic to implement a WSN based on these conversations. Two primary functions of the WSN appeared to interest the grower. First, the ability to view real-time data via SensorWeb was important since the owner also is a commercial airline pilot and thus is off-site frequently. The web-based GUI allows him to monitor water status and adjust irrigation scheduling from any location with Internet capability or cellular service. Second, GDN was interested in reducing irrigation volumes applied, as the nursery is water limited. Largely because of positive comments from the grower at ENI, GDN used the WSNs for monitoring only for 2 weeks, thereafter initiating irrigation control. This rapid switch at GDN from irrigation monitoring to automated irrigation control illustrates the potentially rapid transition from merely monitoring substrate moisture to managing substrate moisture with WSN equipment.

Based on anecdotal grower observations, water use in the WSNcontrolled block has been reduced by $20 \%$ to $25 \%$ and GDN has correspondingly reduced daily irrigation on the 6 acres not controlled by WSNs. This decision was precipitated by observing WSN-controlled irrigation over several months and applying daily WSN-controlled irrigation cycle duration(s) to areas controlled by standard irrigation timers. The result has been a nursery-wide $20 \%$ to $25 \%$ reduction in water use, which may allow the grower to increase his production area without the cost of installing new wells.

\section{Conclusions}

These three case studies exemplify the advancements that can be made in product development, deployment, and implementation when researchers work together with commercial growers. This research project has resulted in successful WSN implementation at three commercial nurseries in Georgia, which now trust and rely on WSN data not only to monitor substrate moisture but also to control irrigation. With the exception of direct lightning strikes that have disabled several nR-5 AC nodes at MNI and ENI, system performance has been reliable. We feel that this issue can be corrected to a large extent by using nR-5 DC nodes that are not hardwired into an irrigation system but connect directly to one (or several) solenoid valves. All three nurseries have indicated that they would invest in a commercially available WSN. Reasons include shorter cropping cycles, reduced disease incidence and severity, less fungicide use, an increased sense of security, and the ability to expand the production area with currently available water resources. Growers have also indicated that the ability to monitor real-time soil moisture and environmental data online is invaluable in making more informed and accurate irrigation decisions. Based on the positive experiences and comments from our grower collaborators, other growers have been eager to try WSNs in their operations. It appears that the limiting factor of wide-scale WSN adoption is the lack of a commercially available WSN hardware and software designed specifically for the ornamental industry.

\section{Literature cited}

Bayer, A., I. Mahbub, M. Chappell, J. Ruter, and M.W. van Iersel. 2013. Water use and growth of Hibiscus acetosella 'Panama Red' grown with a soil moisture sensor controlled irrigation system. HortScience 48:980-987.

Beeson, R.C., Jr. 2004. Modeling actual evapotranspiration of Ligustrum japonicum from rooted cuttings to commercially marketable plants in 12-liter black polyethylene containers. Acta Hort. 664:7177.

Beeson, R.C., Jr. 2010. Modeling actual evapotranspiration of Viburnum odoratissimum during production from rooted cuttings to market size plants in $11.4-\mathrm{L}$ containers. HortScience 45:1260-1264.

Beeson, R.C., Jr. and J. Brooks. 2008. Evaluation of a model based on $\mathrm{ET}_{\mathrm{o}}$ for precision irrigation using overhead sprinklers during nursery production of Ligustrum japonica grown in 11-L containers. Acta Hort. 792:85-90.

Blonquist, J.M., Jr., S.B. Jones, and D.A. Robinson. 2005. Standardizing characterization of electromagnetic water content sensors: Part 2. Evaluation of seven sensing systems. Vadose Zone J. 4:10591069.

Blonquist, J.M., Jr., S.B. Jones, and D.A. Robinson. 2006. Precise irrigation scheduling for turfgrass using a subsurface electromagnetic soil moisture sensor. Agr. Water Mgt. 84:153-165.

Briggs, J., T. Whitwell, M.B. Riley, and T. Lee. 1998. Cyclic irrigation and grass waterways combine to reduce isoxaben losses from container plant nurseries. J. Environ. Hort. 16:235-238.

Burnett, S.E. and M.W. van Iersel. 2008. Morphology and irrigation efficiency of Gaura lindheimeri grown with capacitancesensor controlled irrigation. HortScience 43:1555-1560

Chappell, M., J. Owen, S. White, and J. Lea-Cox. 2013. Irrigation management practices. In: T. Yeager, T. Bilderback, D. Fare, C. Gilliam, J. Lea-Cox, A. Niemiera, 
J. Ruter, K. Tilt, S. Warren, T. Whitwell, and R. Wright (eds.). Best management practices: Guide for producing nursery crops. 3rd ed. 19 Sept. 2013 <http:// contents.sna.org/bmpirrigation.html>.

Crookston, M.A. and M.J. Hattendorf. 2012. Two season comparison of nine smart irrigation controllers. Irr. Show Educ. Conf., Orlando, FL, 4-5 Nov. 2012. p. 381-384.

Ferrarezi, R.S. and M. van Iersel. 2011. Monitoring and controlling subirrigation with soil moisture sensors: A case study with hibiscus. Proc. Southern Nursery Assn. Res. Conf. 56:187-191.

Fischer, G., F.N. Tubiello, H. van Velthuizen, and D.A. Wiberg. 2007. Climate change impacts on irrigation water requirements: Effects on mitigation, 1990-2080. Technol. Forecast. Soc. Change 74:1083-1107.

Garcia-Navarro, M.C., R.Y. Evans, and R.S. Montserrat. 2011. Estimation of relative water use among ornamental landscape species. Sci. Hort. 99:163-174.

Gleeson, T., W.M. Alley, D.M. Allen, M.A. Sophocleous, Y. Zhou, M. Taniguchi, and J. VanderSteen. 2012. Towards sustainable groundwater use: Setting longterm goals, backcasting, and managing adaptively. Ground Water 50:19-26.

Gleick, P.H. 2010. Roadmap for sustainable water resources in southwestern North America. Proc. Natl. Acad. Sci. USA 107:21300-21305.

Howell, T.A. 2001. Enhancing water use efficiency in irrigated agriculture. Agron. J. 93:281-289.

Jones, H.G. 2004. Irrigation scheduling: Advantages and pitfalls of plant-based methods. J. Expt. Bot. 55:2427-2436.

Jones, H.G. 2007. Monitoring plant and soil water status: Established and novel methods revisited and their relevance to studies of drought tolerance. J. Expt. Bot. 58:119-130.

Jury, W.A. and J. Vaux. 2005. The role of science in solving the world's emerging water problems. Proc. Natl. Acad. Sci. USA 102:15715-15720.

Kohanbash, D., G. Kantor, T. Martin, and L. Crawford. 2013. Wireless sensor network design for monitoring and irriga- tion control: User-centric hardware and software development. HortTechnology 23:725-734.

Kim, J. and M. van Iersel. 2009. Daily water use of abutilon and lantana at various substrate water contents. Proc. Southern Nursery Assn. Res. Conf. 54:12-16.

Kim, J. and M. van Iersel. 2010. Photosynthesis and water use of vinca (Catharanthus roseus) during drought: The effect of different drying rates. Proc. Southern Nursery Assn. Res. Conf. 55:114-120.

Kim, J., A. Malladi, and M. van Iersel. 2011. Physiological responses of petunia to different levels of drought stress. Proc. Southern Nursery Assn. Res. Conf. 56:46-51.

Kim, J., B. Belayneh, and J. Lea-Cox. 2012. Estimating daily water use of snapdragon in a hydroponic production system. Proc. Southern Nursery Assn. Res. Conf. 57:336-340.

Knox, J.W., M.G. Kay, and E.K. Weatherhead. 2012. Water regulation, crop production, and agricultural water management: Understanding farmer perspectives on irrigation efficiency. Agr. Water Mgt. 108:3-8.

Lea-Cox, J.D. and D.S. Ross. 2001. A review of the federal clean water act and the Maryland water quality improvement act: The rational for developing a water and nutrient management planning process for container nursery and greenhouse operations. J. Environ. Hort. 19:226229.

Lea-Cox, J.D., W.L. Bauerle, M.W. van Iersel, G.F. Kantor, T.L. Bauerle, E. Lichtenberg, D.M. King, and L. Crawford. 2013. Advancing wireless sensor networks for irrigation management of ornamental crops: An overview. HortTechnology 23:717-724.

Lichtenberg, E., J. Majsztrik, and M. Saavoss. 2013. Profitability of sensorbased irrigation in greenhouse and nursery crops. HortTechnology 23:770-774.

Miralles-Crespo, J. and M. van Iersel. 2011. A calibrated time domain transmissiometry soil moisture sensor can be used for precise automated irrigation of container-grown plants. HortScience 46:889-894.
Nautiyal, M., G. Grabow, G. Miller, and R.L. Huffman. 2010. Evaluation of two smart irrigation technologies in Cary, North Carolina. Proc. Amer. Soc. Agr. Biol. Eng. Conf. Paper No. 1009581.

O'Meara, L., M. Chappell, and M. van Iersel. 2011. Water consumption of Hydrangea macrophylla as affected by environmental factors. Proc. Southern Nursery Assn. Res. Conf. 56:162-166.

Peter, A.O., P.A. Thomas, and M. van Iersel. 2011. Growth of petunia as affected by substrate moisture content and fertilizer rate. Proc. Southern Nursery Assn. Res. Conf. 56:167-172.

Tyler, H.H., S.L. Warren, and T.E. Bilderback. 1996. Cyclic irrigation increases irrigation application efficiency and decreases ammonium losses. J. Environ. Hort. 14:194-198.

van Iersel, M., J. Kang, and S. Burnett. 2007. Making greenhouse irrigation more efficient: Effects of substrate water content on the growth and physiology of vinca (Catharanthus roseus). Proc. Southern Nursery Assn. Res. Conf. 52:92-96.

van Iersel, M., R.M. Seymour, M. Chappell, F. Watson, and S. Dove. 2009. Soil moisture sensor-based irrigation reduces water use and nutrient leaching in a commercial nursery. Proc. Southern Nursery Assn. Res. Conf. 54:17-21.

van Iersel, M.W., M. Chappell, and J.D. Lea-Cox. 2013. Sensors for improved efficiency of irrigation in greenhouse and nursery production. Hort Technology 23:735-746.

Warsaw, A.L., R.T. Fernandez, B.M. Cregg, and J.A. Andresen. 2009. Water conservation, growth, and water use efficiency of container-grown woody ornamentals irrigated based on daily water use. HortScience 44:1308-1318.

Wilson, P.C. and J.P. Albano. 2011. Impact of fertigation versus controlledrelease fertilizer formulations on nitrate concentrations in nursery drainage water. HortTechnology 21:176-180.

Wu, P., J. Jin, and X. Zhao. 2010. Impact of climate change and irrigation technology advancement on agricultural water use in China: A letter. Clim. Change 100:797-805. 